Jasmina U. Klemenović, Stanislava D. Marić Jurišin DOI: 10.19090/zop.2016.25.41-56 Univerzitet u Novom Sadu, UDC: $316.61-053-4: 316.45 / .48$ Filozofski fakultet Jelena Nikolić

\title{
POVEZANOST SOCIJALNE KOMPETENTNOSTI DECE PREDŠKOLSKOG UZRASTA SA PRIHVATANJEM U GRUPI I ANTISOCIJALNIM PONAŠANJEM ${ }^{1}$
}

Apstrakt: Tokom prvih godina života dete uspostavlja različite socio-emocionalne odnose koji oblikuju njegov psiho-socijalni razvoj. Pored prihvatanja od strane članova porodice, u socijalizaciji deteta od posebnog značaja su odnosi i prihvaćenost od strane vršnjaka. Socijalno kompetentno dete koristi različite podsticaje iz okoline, kao i svoje lične veštine i interesovanja, za učestvovanje u zajednici kojoj pripada. Razvoj i učenje deteta značajno su otežani ukoliko podsticaji za interakcijom izostaju ili duže vreme bivaju ometani neadekvatnim ponašanjem deteta i/ili vršnjačkim neprihvatanjem. Sa namerom da se preventivno deluje, dizajnirano je istraživanje u pet pripremnih grupa jedne predškolske ustanove u Vojvodini. Cilj istraživanja bile su veze između socijane kompetentnosti dece $(\mathrm{N}=120)$ i prihvaćenosti u grupi vršnjaka, te njihove sklonosti ka antisocijalnom ponašanju. Nalazi dobijeni skaliranjem i sociometrijom pokazuju da se predškolci međusobno značajno razlikuju u prihvaćenosti, socijalnom i antisocijanom ponašanju, pri čemu je uspostavljena značajna pozitivna korelacija između socijalne kompetentnosti i broja godina provedenih u ustanovi, dok su devojčice procenjene kao prihvaćenije i kompetentnije. Primećena je i značajna negativna povezanost između odbijanja i socijalne kompetentnosti kod dečaka, te antisocijalnog ponašanja i procenjene kompetentnosti dece među predškolcima ukupno, bez obzira na pol. Ustanovljeno je da antisocijalno ponašanje nije značajnije povezano sa brojem godina provedenih u ustanovi. Omogućavanje podsticajnih uslova za jačanje socijalne kompetentnosti i rano identifikovanje dece kojoj je potrebna dodatna podrška za uspostavljanje i građenje odnosa sa vršnjacima temeljni su zadaci svih koji su u kontaktu sa decom predškolskog

\footnotetext{
${ }^{1}$ Jasmina Klemenović, klementina@ff.uns.ac.rs, Stanislava Marić, Jurišin stashamaric@ ff.uns.ac.rs, Jelena Nikolić,jelenanikolic8@gmail.com

Rad je nastao u okviru naučno-istraživačkog projekta „Pedagoški pluralizam kao osnova strategije obrazovanja“ čiju realizaciju finansira Ministarstvo prosvete, nauke i tehnološkog razvoja Republike Srbije (2011-2016).
} 
uzrasta, posebno onih koji deluju u okviru predškolskih ustanova.

Ključne reči: socijalna kompetentnost, prihvaćenost u vršnjačkoj grupi, antisocijalno ponašanje, programi vežbanja socijalnih veština.

\section{Uvod}

Dete ranog uzrasta doživljava svoju okolinu kroz odnose koje uspostavlja i razvija od prvih dana svog života. Najpre majka, otac, braća, sestre i drugi članovi porodice podstiču i usmeravaju detetova prva iskustva i na različite načine ga uvode u kulturnu praksu sticanjem novih veština i načina komunikacije kojima ostvaruje uspešno uključivanje u zajednicu (Anning, Cellen \& Fleer, 2004). Uspešna integracija u zajednicu direktno je povezana sa socijalnim razvojem deteta, odnosno njegovom socijalnom kompetencijom. Od posebnog značaja za razvoj i učenje je uspešna integracija u grupu vršnjaka. U vršnjačkoj grupi dete razvija i zadovoljava potrebu za intimnošću, formira sliku o sebi, uči kako da se ponaša, da deli i sarađuje, pomaže drugima, poštuje pravila, da se nosi sa pobedom i porazom. U odnosima sa vršnjacima deca izgrađuju svoje socijalne veštine. Uče načine interakcije sa drugima, što utiče na njihovo ponašanje tokom detinjstva ali i kasnije u životu. Potpuno izostajanje prilika za kontinuiranim kontaktom sa drugom decom, baš kao i neprihvatanje (odbacivanje) od strane vršnjaka ili dugotrajni i učestali problemi u interakciji sa njima, mogu se smatrati znakom da je dete pod rizikom. Naime, emocionalne teškoće i problemi u ponašanju otežavaju uključivanje u igru i vode smanjenju interakcija sa vršnjacima, što nepovoljno deluje na celokupni razvoj i učenje deteta. Mnogi autori ukazuju na potrebu preispitivanja "začaranog kruga" veza koje se javljaju između (ne)prihvatanja deteta $u$ grupi vršnjaka, pojave antisocijalnog ponašanja i izgrađivanja socijalne kompetentnosti u ranom i predškolskom detinjstvu.

\section{Određenje socijalne kompetentnosti}

Pregled dostupne literature i relevantnih istraživanja ukazuje da se socijalne kompetencije definišu na više načina i sa različitih polazišta. Primetno je da među autorima ne postoji konsenzus oko jedinstvenog značenja ovog termina, ali je simptomatična i cirkularnost ovako velikog broja različitih definicija. Može se konstatovati da se pod socijalnom 
kompetentnošću najčešće podrazumevaju različite socijalne, emocionalne i kognitivne veštine koje su potrebne za uspešnu socijalnu adaptaciju, u čijem je središtu efikasnost socijalnih interakcija (Dodge, 1985; Petrović, 2006; Rubin \& Rose-Krasnor, 1992, prema Marić-Jurišin, 2015). Iako pojedini autori izjednačavaju socijalne kompetencije sa socijalnim veštinama, važno je i pored izvesnih zajedničkih obeležja napraviti razliku među njima. Socijalne veštine obuhvataju niz socijalnih ponašanja koja su naučena i pod kontrolom su pojedinca, dok kompetencija određuje način na koji pojedinac primenjuje te veštine na druge kontekste ili situacije (Ladd, 2005). To znači da je uvek na delu socijalna kompetentnost pojedinca onda kada se socijalne veštine primenjuju na odgovarajući način i omogućavaju ostvarivanje ličnih ciljeva (prema Jurčević-Lozančić, 2011).

Prema modelu Rouz-Krasnor (1997), da bi se dete ponašalo socijalno kompetentno, ono mora biti efikasno u socijalnim interakcijama, dok prihvaćenost u grupi vršnjaka zavisi od toga kako druga deca reaguju na ponašanje pojedinca. Pritom je socijalna kompetentost relativna u odnosu na specifične ciljeve od kojih će dalje zavisiti da li će jedno ponašanje biti procenjeno kao socijalno kompetentno ili ne. Za jednu osobu jedan određeni cilj može biti procenjen kao značajan, adaptivan i odgovarajući, dok za drugu osobu on to nije. Stoga je važno sagledati socijalne ciljeve iz razvojne perspektive. Polaskom u predškolsku ustanovu i stavljanjem deteta u situaciju uključivanja u novu zajednicu (vršnjačku grupu), najveći izazov postaje adaptacija na novu sredinu i prihvatanje deteta kao njenog ravnopravnog člana. Stoga se deca razlikuju u pogledu stepena važnosti koju pridaju prihvatanju od strane vršnjaka i isticanju razlike između domena „Ja“ (uspešnost u postizanju sopstvenih ciljeva i osećanje lične efikasnosti u socijalnim interakcijama) i domena „Drugi“ (kvalitet prijateljskih odnosa, sociometrijski status, kvalitet odnosa ostvaren unutar socijalne mreže). Dakle, koliko je dete efikasno u socijalnim interakcijama, uspešno u postizanju sopstvenih ciljeva i da li se više ponaša socijalno kompetntno, možemo da pretpostavimo da će biti prihvaćenije u grupi nego ukoliko se ponaša antisocijalno (prema Petrović i Zotović, 2007). To implicira da je socijalno kompetentno ono dete koje je društveno osetljivo, koje poseduje socijalno poželjna ponašanja i socijalno-kognitivne sposobnosti koje mu omogućavaju da svoja različita ponašanja primeni na način usklađen $\mathrm{s}$ potrebama druge dece.

Iako je u istraživanjima dečjeg razvoja dugi niz godina zanemarivan aspekt socijalnog razvoja, poslednjih se decenija situacija 
značajno promenila (Brown, 1996; Goleman, 2008; Fuller, 2008; Howes \& Ritchie, 2002; Ladd, 2005; Katz \& McClelan, 2005; Rose-Krasnor, 1997; Williamson \& Dorman, 2002, prema Jurčević-Lozančić, 2011). Tome su na izvestan način doprinele studije koje čiji su autori uočili vezu između problematičnih odnosa u vršnjačkoj grupi i lošijeg akademskog postignuća (Buhs \& Ladd, 2001; Keane \& Calkins, 2004; Warden \& Mackinnon, prema Klemenović, 2014), kao i oni koje su ukazali na mogućnosti jačanja socijalne kompetentnosti predškolske dece primenom različitih preventivnih programa rizičnog ponašanja (Bašić, 2012). Većina savremenih teorija bazira se na pretpostavci da su razvijene socijalne kompetencije preduslov za ostvarivanje pozitivnih socijalnih odnosa a samim tim i prihvaćenosti deteta u zajednici vršnjaka.

\section{Metodologija istraživanja}

U savremenim uslovima života, posebno u urbanim sredinama, važne činioce socijalne sredine predstavljaju različiti programi zajednice i institucionalnog predškolskog vaspitanja i obrazovanja koji se realizuju u predškolskim ustanovama. Uključujući se u takve programe, deca su u prilici da uspostavljaju interakciju sa različitim odraslima i grade odnose sa vršnjacima čije prihvatanje predstavlja važnu komponentu dečijeg razvoja. Ukoliko deca tokom takvih interakcija uspevaju da odgovore na svoje lične potrebe ali i potrebe druge dece te izražavaju više pozitivnih emocija i češće reaguju prosocijalno, verovatnije će lakše prevladati izazove u grupnoj interakciji. Deca koja nisu prihvaćena u grupi i ne uspevaju da održe odnose sa vršnjacima pod većim su rizikom manifestovanja svog antisocijalnog ponašanja. Otuda se predmet istraživanja najkraće može odrediti kao utvrđivanje socijalne kompetentnosti dece predškolskog uzrasta ispitivanjem veze između antisocijalnog ponašanja i prihvaćenosti u grupi vršnjaka.

$\mathrm{Na}$ osnovu analize relevantne literature, prethodnih istraživanja i formulisanog predmeta, cilj ovog istraživanja je ispitati da li se predškolci razlikuju međusobno po prihvaćenosti u grupi vršnjaka, socijalno kompetentnom i antisocijalnom ponašanju, te ustanoviti prisustvo korelacije među ovim fenomenima, kao i u odnosu na razlike prema polu dece i vremenu provedenom u ustanovi. Postavljeni istraživački cilj konkretizovan je kroz četiri zadatka: 1) sagledati socijalni status pojedinog deteta u grupi i utvrditi da li postoji razlika u socijalnoj kompetentnosti i 
antisocijalnom ponašanju prema polu deteta; 2) utvrditi postoji li povezanost između socijalne kompetentnosti dece predškolskog uzrasta i stepena prihvaćenosti; 3) utvrditi da li postoji korelacija između antisocijalnog ponašanja dece predškolskog uzrasta i stepena prihvaćenosti i 4) utvrditi da li postoji korelacija socijalnog statusa, socijalne kompetentnosti i antisocijalnog ponašanja u odnosu na pol i vreme provedeno u ustanovi.

Opšta pretpostavka je da se deca predškolskog uzrasta razlikuju međusobno kada je reč o prihvaćenosti, socijalnoj kompetentnosti i antisocijalnom ponašanju prema kriterijumu pola i vremena provedenog u predškolskoj ustanovi. Drugim rečima, pretpostavka je da se javljaju razlike između devojčica i dečaka s obzirom na: prihvaćenost u grupi vršnjaka, nivo socijalne kompetentnosti i antisocijalno ponašanje (H1), kao i da postoji povezanost između socijalne kompetentnosti dece predškolskog uzrasta i stepena njihove prihvaćenosti u grupi (H2); zatim, povezanost između antisocijalnog ponašanja dece predškolskog uzrasta i stepena prihvaćenosti (H3), kao i povezanost između socijalnog statusa, socijalne kompetentnosti i antisocijalnog ponašanja u odnosu na vreme provedeno u ustanovi i za devojčice i za dečake $(\mathrm{H} 4)$.

Metode $i$ instrumenti istraživanja - Zbog prirode problema koji se ispituje $u$ istraživanju korišćena je deskriptivna metoda. Od tehnika primenjeni su: skaliranje - za procenu socijalne kompetentnosti svakog deteta i sociometrija - koja omogućava proučavanje odnosa u grupi i u celini i u delovima. Za potrebe istraživanja preuzeta je, uz blago prilagođavanje, Skala procene socijalnog ponašanja učenika u školi (School Social Behavior Scale - SSBS-2), čiji je autor K. W Merel (Merrell, 2002). Skala SSBS-2 sastoji se iz 63 stavke i dve skale. Skala A - Socijalna kompetentnost - sadrži 31 tvrdnju u okviru tri podskale (interpersonalne veštine, veštine samokontrole i akademske veštine); Skala B - Antisocijalno ponašanje - obuhvata 32 tvrdnje organizovane u tri podskale, i to: neprijateljskoiritativni, antisocijalno-agresivni, zahtevno-remetilački (prema Potkonjak i sar., 2008). Na predstavljenim skalama vaspitači su procenjivali socijalno ponašanje svakog deteta iz grupe pojedinačno. Uz adaptiranu Merelovu skalu procene, korišćen je i sociometrijski upitnik, posredstvom kojeg je svako dete nominovalo tri člana iz grupe sa kojima bi volelo da se igra i tri člana sa kojim to ne bi, na osnovu čega je izrađena sociometrijska matrica.

Populacija $i$ uzorak istraživanja - Populaciju su činili deca i vaspitači Predškolske ustanove „Petar Pan“ iz Malog Iđoša, dok je uzorak namenski i prigodni - 120 dece predškolskog uzrasta $(\mathrm{N}=120)$ iz pet 
mešovitih pripremnih grupa $(5,5 / 6,5$ godina) i 5 vaspitača tih vaspitnih grupa, u kojima je primenjen sociometrijski upitnik kojim su deca procenjivana na skali namenjenoj proceni dečijeg ponašanja - Tabela 1 .

Tabela 1 - Uzorak istraživanja

\begin{tabular}{lllllllll}
\hline Pripremna grupa & $1 \mathrm{PG}$ & 2PG & 3PG & 4PG & 5PG & $\mathrm{f}$ & $\%$ \\
\hline Vaspitači & & 1 & 1 & 1 & 1 & 1 & 5 & $100 \%$ \\
\hline DECA & & 27 & 19 & 21 & 25 & 28 & 120 & $100 \%$ \\
\hline Pol dece & $\mathrm{m}$ & 13 & 9 & 12 & 16 & 14 & 68 & $51,7 \%$ \\
\cline { 2 - 9 } & $\check{z}$ & 14 & 10 & 9 & 9 & 14 & 52 & $48,3 \%$ \\
\hline $\begin{array}{l}\text { Godina } \\
\text { rođenja } \\
\text { dece }\end{array}$ & 2008 & 11 & 4 & 5 & 21 & $/$ & 41 & $34,2 \%$ \\
\hline \multirow{nyyyyyyyy}{*}{$\begin{array}{l}\text { Godina } \\
\text { upisa dece }\end{array}$} & 2009 & 16 & 11 & 7 & 4 & 14 & 52 & $43,3 \%$ \\
\cline { 2 - 8 } & 2010 & $/$ & 4 & 9 & $/$ & 14 & 27 & $22,5 \%$ \\
\cline { 2 - 8 } & 2010 & $/$ & $/$ & $/$ & 3 & $/$ & 3 & $2,5 \%$ \\
\cline { 2 - 8 } & 2011 & 4 & 1 & $/$ & 4 & $/$ & 9 & $7,5 \%$ \\
\hline & 2012 & 19 & 1 & 4 & 1 & $/$ & 25 & $20,8 \%$ \\
\hline
\end{tabular}

Organizacija istraživanja - Istraživanje je realizovano tokom drugog polugodišta školske 2014/2015. godine. Paralelno sa izradom sociometrijskih matrica, na osnovu ispitivanja dece u svakoj od vaspitnih grupa, uz pomoć vaspitača obavljena je i procena socijalne kompetentnosti svakog deteta pojedinačno u grupi.

Obrada podataka - Nakon obavljenog istraživanja, izvršena je priprema podataka za statističku analizu. Prilikom kvantitativne obrade podataka korišćen je SPSS program za statistička izračunavanja mera i postupaka iz domena deskriptivne statistike. U cilju potpunijeg uvida u relacije između ispitivanih varijabli i poređenja rezultata dečaka i devojčica, urađena je i Pirsonova linearna korelacija između varijabli kojima se procenjuju socijalni status i socijalno kompetentno i antisocijalno ponašanje.

\section{Analiza i interpretacija rezultata}

Iako se prilagođeni Merelov instrument sastoji iz dve skale za procenu socijalnog ponašanja dece predškolskog uzrasta i sociometrijskih 
matrica, u nastavku analize prikazani su rezultati i statistička obrada samo onih koji su u direktnoj vezi sa istraživačkim zadacima.

Rezultati prikupljeni upitnicima podvrgnuti su deskriptivnoj statističkoj analizi i primenom neparametrijskih statističkih testova.

Prvi zadatak istraživanja usmeren je na sagledavanje socijalnog statusa svakog pojedinog deteta u grupi i utvrđivanje razlike u socijalnoj kompetentnosti i antisocijalnom ponašanju dečaka i devojčica. U tu svrhu izrađene su sociometrijske matrice u svih pet vaspitnih grupa uključenih $\mathrm{u}$ istraživanje. Kako bi se odgovorilo na postavljene probleme, rezultati istraživanja analizirani su odvojeno s obzirom na pol dece - Tabela 2.

Tabela 2 - Paranetri za procenu sociometrijskog statusa prema polu dece $i$ značajnost razlika aritmetičke sredine

\begin{tabular}{|c|c|c|c|c|c|c|c|c|c|}
\hline \multirow[t]{2}{*}{ Varijabla } & \multirow{2}{*}{$\frac{M}{\mathbf{m}}$} & \multicolumn{2}{|l|}{$M$} & \multirow{2}{*}{ df } & \multirow[b]{2}{*}{$\mathbf{p}$} & \multirow[b]{2}{*}{ m } & \multirow[t]{2}{*}{$N$} & \multirow{2}{*}{$\frac{S D}{\mathrm{~m}}$} & \multirow{2}{*}{$\frac{S D}{\check{\mathbf{z}}}$} \\
\hline & & $\check{\mathbf{Z}}$ & $\mathbf{t}$ & & & & & & \\
\hline IPR & 0,1347 & 0,1279 & 0,347 & 118 & 0,730 & 62 & 58 & 0,11214 & 0,10022 \\
\hline IOD & 0,1760 & 0,0733 & 4,266 & 118 & 0,000 & 62 & 58 & 0,15097 & 0,10750 \\
\hline ISS & $-0,0421$ & 0,0550 & $-2,807$ & 118 & 0,006 & 62 & 58 & 0,21716 & 0,15408 \\
\hline Skala A & 78,7742 & 84,1552 & $-2,922$ & 118 & 0,004 & 62 & 58 & 10,203 & 9,949 \\
\hline Skala B & 38,9839 & 34,6207 & 2,969 & 118 & 0,004 & 62 & 58 & 9,548 & 6,031 \\
\hline
\end{tabular}

Analiza rezultata iz Tabele 2 za prosečne vrednosti sociometrijskih indeksa na uzorku u celini kreće se od $-0,421$ do 0,1760 . Na osnovu vrednosti standardne devijacije, evidentna je blaga razlika u homogenosti rezultata; nešto je slabija homogenost kod varijable ISS nego kod IOD i IPR. Takođe, primetna je blaga razlika u homogenosti između muških i ženskih ispitanika. Vrednosti aritmetičkih sredina indeksa prihvatanja za dečake i devojčice su približno iste, dok postoji razlika u vrednostima aritmetičke sredine indeksa odbijanja. Ovo je rezultiralo razlikom i u vrednostima aritmetičke sredine socijalnog statusa. Te razlike vide se i u vrednostima t. Tabelarna vrednost $\mathrm{t}$ za stepen slobode 118 za nivo značajnosti 0.05 iznosi 1,982, a za nivo značajnosti $0,01-2,635$. Računske t-vrednosti upoređuju se sa tabelarnim vrednostima pa se dolazi do zaključka da nema značajne razlike između polova dece za indeks prihvatanja $(\mathrm{t}=0,347)$, dok za indeks odbijanja $(\mathrm{t}=4,266)$ i indeks socijalnog statusa $(\mathrm{t}=-2,807)$ 
postoje značajne razlike između dece različitog pola. Sa druge strane, upoređujući aritmetičke sredine dobijene za socijalnu kompetentnost $i$ antisocijalno ponašanje s obzirom na pol, rezultati ukazuju da se dečaci i devojčice razlikuju u socijalnoj kompetentnosti $(-2,992)$ i antisocijalnom ponašanju $(2,969)$, i da je ta razlika statistički značajna. Ovim rezultatima potvrđena je prva posebna hipoteza da se dečaci i devojčice razlikuju u stepenu prihvaćenosti u grupi, socijalnoj kompetentnosti i antisocijalnom ponašanju.

Kao sledeći korak u analizi podataka, utvrđeni su koeficijenti Pirsonove linearne korelacije između socijalne kompetentnosti i sociometrijskog statusa na celokupnom uzorku dece. S obzirom na to da se drugom hipotezom htelo potvrditi da li postoji korelacija između socijalno kompetentnog ponašanja i stepena prihvaćenosti u grupi, analizom rezultata iz Tabele 3 uočava se da postoji korelacija između varijabli za procenu socijalne kompetentnosti i indeksa prihvatanja i sociometrijskog statusa na nivou značajnosti .01, dok je korelacija socijalne kompetentnosti i indeksa odbijanja značajno negativna $(\mathrm{r}=.-0,407 ; \mathrm{p}<.01)$.

Tabela 3 - Pirsonov koeficijent linearne korelacije za procenu socijalne kompetentnosti i varijabli za procenu sociometrijskog statusa sve dece

\begin{tabular}{lllll}
\hline & & IPR & IOD & ISS \\
\hline $\begin{array}{l}\text { Skala A (Socijalna } \\
\text { kompetentnost) }\end{array}$ & Pirsonov koef. & $0,256^{* *}$ & $-0,407^{* *}$ & $0,258^{* *}$ \\
\cline { 2 - 5 } & $\mathrm{P}$ & 0,005 & 0,000 & 0,004 \\
\hline
\end{tabular}

**korelacija je statistički značajna na nivou značajnosti .01

Ovim zaključkom može se potvrditi pretpostavka da postoji niska korelacija između socijalne kompetentnosti dece predškolskog uzrasta indeksa prihvatanja $(\mathrm{r}=0,256 ; \mathrm{p}<.01) \mathrm{i}$ indeksa socijalnog statusa $(\mathrm{r}=0,258$; $\mathrm{p}<.01$ ). To znači da što je dete socijalno kompetentnije - ono ima više pozitivnih, odnosno manje negativnih biranja od vršnjaka iz svoje grupe. Ovim zaključcima potvrđuje se druga hipoteza istraživanja, odn. da postoji povezanost između socijalne kompetentnosti $i$ stepena prihvaćenosti $u$ grupi.

Dalje, podaci iz Tabele 4 pokazuju da postoji značajna korelacija između antisocijalnog ponašanja i indeksa odbijanja na nivou značajnosti .01, što znači da deca koja se ponašaju antisocijalno često u grupi bivaju odbijena, odnosno dobijaju više negativnih biranja od svojih vršnjaka, 
što nije slučaj za varijablu indeksa prihvatanja i socijalnog statusa gde ne postoji korelacija, odnosno korelacija je samo neznatno negativna. Može se zaključiti da je opravdano smatrati da je - što se dete više ponaša antisocijalno - indeks odbijanja veći $(\mathrm{r}=0,451 ; \mathrm{p}<.01)$, čime je i treća hipoteza da postoji korelacija između antisocijalnog ponašanja i stepena prihvaćenosti u grupi potvrđena.

Tabela 4 - Pirsonov koeficijent linearne korelacije za procenu antisocijalnog ponašanja $i$ varijabli za procenu sociometrijskog statusa sve dece

\begin{tabular}{lllll}
\hline & & IPR & IOD & ISS \\
\hline $\begin{array}{l}\text { Skala B (Antisocijalno } \\
\text { ponašanje) }\end{array}$ & Pirsonov koef. & $-0,063$ & $0,451^{* *}$ & $-0,089$ \\
\cline { 2 - 5 } & $\mathrm{P}$ & 0,496 & 0,000 & 0,335 \\
\hline
\end{tabular}

**korelacija je statistički značajna na nivou značajnosti .01

Rezultati stepena povezanosti indeksa prihvatanja, odbijanja i socijalnog statusa, broja godina provedenih u vrtiću, socijalne kompetentnosti i antisocijalnog ponašanja na ukupnom uzorku prikazani su u Tabeli 5, dok su u Tabeli 6 prikazani rezultati posebno za dečake posebno za devojčice.

Tabela 5 - Korelacija varijabli istraživanja za celokupan uzorak $\begin{array}{lllll}\text { god. u } & \text { IPR } & \text { IOD } & \text { ISS } & \text { Skala A }\end{array}$ PU

\begin{tabular}{|c|c|c|c|c|c|}
\hline $\begin{array}{l}\text { god. u } \\
\text { PU }\end{array}$ &, $369^{* *}$ &,- 074 &, $389^{* *}$ &, $190^{*}$ &,- 046 \\
\hline IPR & &,$- 221^{*}$ &, $884^{* *}$ &, $256^{* *}$ &,- 063 \\
\hline IOD & & &,- 102 &,$- 407^{* *}$ &, $451^{* *}$ \\
\hline ISS & & & &, $258^{* *}$ &,- 089 \\
\hline Skala A & & & & &,$- 423^{* *}$ \\
\hline
\end{tabular}

Skala B

*Korelacija je značajna na nivou značajnosti .05; **Korelacija je značajna na nivou značajnosti .01 
Granične vrednosti linearnog koeficijenta korelacije $\mathrm{r} u$ slučaju celokupnog uzorka za stepen slobode $\mathrm{df}=118$ i nivo značajnosti .05 iznosi 0,189 , a za nivo značajnosti $.01-0,247$, dok u slučaju uzorka dečaka $\left(\mathrm{N}_{1}=62\right)$ za stepen slobode $\mathrm{df}=60$ i nivo značajnosti .05 iznosi 0,25 , a za nivo značajnosti $.01-0,325$. U slučaju uzorka devojčica $\left(\mathrm{N}_{2}=58\right)$, granične vrednosti linearnog koeficijenta korelacije $\mathrm{r}$ za stepen slobode $\mathrm{df}=56 \mathrm{i}$ nivo značajnosti .05 iznosi 0,259 , a za nivo značajnosti $.01-0,337$.

Rezultati ukazuju da je utvrđena značajna niska pozitivna povezanost sociometriskog statusa i socijalno kompetentnog ponašanja na celom uzorku $(\mathrm{r}=0,258 ; \mathrm{p}<.01)$, ali na uzorku devojčica $(\mathrm{r}=0,118 ; \mathrm{p}<.05)$ je ta povezanost manje izražena nego na uzorku dečaka $(\mathrm{r}=0,411 ; \mathrm{p}<.01)$. Dalje, ne postoji značajna korelacija između sociometrijskog statusa i antisocijalnog ponašanja na celokupnom uzorku $(\mathrm{r}=-0,089 ; \mathrm{p}<.05)$, dok se kod dečaka primećuje značajna negativna povezanost $(\mathrm{r}=-0,264 ; \mathrm{p}<.05)$, a kod devojčica nema značajne povezanosti ovih varijabli $(\mathrm{r}=0,184$; $\mathrm{p}<.05$ ). Posmatrajući odnos sociometrijskog statusa i broja godina u vrtiću na celokupnom uzorku, vidi se značajna pozitivna povezanost $(\mathrm{r}=0,389$; $\mathrm{p}<.01)$. Slično je i na odvojenim uzorcima za dečake $(\mathrm{r}=0,345 ; \mathrm{p}<.01) \mathrm{i}$ za devojčice $(r=0,441 ; p<.01)$. Socijalna kompetentnost je u značajnoj pozitivnoj povezanosti sa brojem godina provedenim u ustanovi za celokupni uzorak $(\mathrm{r}=0,190 ; \mathrm{p}<.05)$, dok ne postoji značajna povezanost u odvojenim uzorcima za dečake $(r=0,207 ; \mathrm{p}<.05)$ i devojčice $(r=0,160$; $\mathrm{p}<.05$ ). Antisocijalno ponašanje za sva tri slučaja (ukupan uzorak, dečaci i devojčice) nije značajno povezano sa brojem godina provedenim u vrtiću $(\mathrm{r}=-0,046 ; \mathrm{p}<.05 ; \mathrm{r}=-0,002 ; \mathrm{p}<.05$ i $\mathrm{r}=-0,100 ; \mathrm{p}<.05)$. Među varijablama socijalne kompetentnosti i antisocijalnog ponašanja dece utvrđena je značajna negativna povezanost na ukupnom uzorku, kao i na pojedinačnim uzorcima za dečake i devojčice $(\mathrm{r}=-0,423 ; \mathrm{p}<.01 ; \mathrm{r}=-0,396 ; \mathrm{p}<.01 \mathrm{r}=0,375$; $\mathrm{p}<.01)$. Ovom analizom možemo zaključiti da je četvrta hipoteza delimično potvrđena. 
Tabela 6 - Korelacija varijabli istraživanja prema polu (Napomena: iznad dijagonale dati su rezultati za dečake, a ispod dijalgonale za devojčice)

\begin{tabular}{lcccccc}
\hline & $\begin{array}{c}\text { god. u } \\
\text { PU }\end{array}$ & IPR & IOD & ISS & Skala A & Skala B \\
\hline $\begin{array}{l}\text { god. u } \\
\text { PU }\end{array}$ & &, $392^{* *}$ &,- 131 &, $345^{* *}$ &, 207 &,- 002 \\
\hline IPR &, $346^{* *}$ & &,$- 373^{* *}$ &, $910^{* *}$ &, $438^{* *}$ &,- 233 \\
\hline IOD &,- 063 &,- 001 & &,$- 304^{* *}$ &,$- 476^{* *}$ &, $374^{* *}$ \\
\hline ISS &, $441^{* *}$ &, $855^{* *}$ &,- 210 & &, $411^{* *}$ &,$- 264^{*}$ \\
\hline Skala A &, 160 &, 058 &,- 117 &, 118 & &,$- 396^{* *}$ \\
\hline Skala B &,- 100 &,- 248 &, $433^{* *}$ &, 184 &,$- 375^{* *}$ & \\
\hline
\end{tabular}

*Korelacija je značajna na nivou značajnosti .05; **Korelacija je značajna na nivou značajnosti .01

\section{Diskusija}

U savremenim uslovima života, posebno u urbanim sredinama, važne činioce socijalnog razvoja predstavljaju različiti programi koji se realizuju u predškolskim ustanovama. Uključujući se u takve programe, deca su u prilici da uspostavljaju interakciju sa raznim odraslim osobama i grade odnose sa vršnjacima čije prihvatanje predstavlja važnu komponentu dečijeg razvoja. Ukoliko deca tokom takvih interakcija uspevaju da odgovore na svoje lične potrebe ali i potrebe druge dece, izražavaju više pozitivnih emocija i češće reaguju prosocijalno, verovatnije će lakše prevladati izazove u grupnoj interakciji. Deca koja nisu prihvaćena u grupi i koja ne uspevaju da održe odnose sa vršnjacima pod većim su rizikom da se kod njih manifestuju antisocijalna ponašanja. Otuda je cilj istraživanja bio ustanoviti da li se javlja razlika među decom predškolskog uzrasta $\mathrm{s}$ obzirom na prihvaćenost $u$ grupi vršnjaka, te na socijalno kompetentno i antisocijalno ponašanje, postoji li tu povezanost, te u kojoj meri deluju razlike u polu dece i vremenu provedenom u predškolskoj ustanovi.

Pretpostavilo se da se deca razlikuju u prihvaćenosti, socijalno kompetentnom i antisocijalnom ponašanju u odnosu na pol te da postoji korelacija između svih ovih varijabli, što je ujedno bila opšta i prva posebna hipoteza. Upoređivanje izračunatih $\mathrm{t}$-vrednosti sa tabelarnim vrednostima pokazalo je da ne postoji značajna razlika po polu dece za 
indeks prihvatanja $(\mathrm{t}=0,347)$, dok je ona evidentna za indeks odbijanja $(\mathrm{t}=4,266) \mathrm{i}$ indeks socijalnog statusa $(\mathrm{t}=-2,807)$. Tako je ustanovljeno da su devojčice socijalno prihvaćenije od dečaka, što je potvrđeno i procenama koje su obavili vaspitači. Naime, upoređujući vrednosti aritmetičkih sredina socijalne kompetentnosti i antisocijalnog ponašanja dobijenih u odnosu na pol, rezultati ukazuju da se dečaci i devojčice razlikuju u socijalnoj kompetentnosti $(-2,992)$ i antisocijalnom ponašanju $(2,969)$ i da je ta razlika statistički značajna - vaspitači su procenili devojčice socijalno kompetentnijima u odnosu na dečake. Dakle, na osnovu rezultata istraživanja, potvrđena je opšta i prva posebna hipoteza prema kojoj se deca predškolskog uzrasta razlikuju po prihvaćenosti, socijalnoj kompetentnosti i antisocijalnom ponašanju u odnosu na pol. Dobijeni rezultati su u skladu sa drugim istraživanjima iz ove oblasti (na primer, Bašić, Ferić i Kranželić, 2001; Bašić, Ferić-Šlehan i Kranželić -Tvara, 2007; Bašić, 2008), koji pokazuju da su devojčice u prednosti u odnosu na dečake, čije se ponašanje češće ocenjuje kao agresivno odnosno zavisno i/ ili depresivno (prema Bašić, 2012: 499).

Statistička obrada podataka u vezi sa drugom posebnom istraživačkom hipotezom pokazala je da se može tvrditi da postoji korelacija između socijalne kompetentnosti dece predškolskog uzrasta i indeksa prihvatanja $(\mathrm{r}=0,256 ; \mathrm{p}<.01)$ te indeksa socijalnog statusa $(\mathrm{r}=0,258 ; \mathrm{p}<.01)$, dok je korelacija socijalne kompetentnosti i indeksa odbijanja statistički negativno značajna $(r=.-0,407 ; p<.01)$. To znači da - što je socijalno kompetentnije - dete ima više pozitivnih odnosno manje negativnih biranja od vršnjaka iz svoje grupe. Provera treće posebne istraživačke hipoteze o postojanju korelacije između antisocijalnog ponašanja i stepena prihvaćenosti u grupi dece predškolskog uzrasta može se potvrditi budući da su podaci ukazali na postojanje značajne korelacije između antisocijalnog ponašanja i indeksa odbijanja na nivou značajnosti .01, što znači da deca koja se ponašaju antisocijalno u grupi često bivaju odbijena, odnosno dobijaju više negativnih biranja od svojih vršnjaka. Dobijeni rezultati nisu u potpunosti podudarni sa sličnim istaživanjima (npr., Glavina, VišnjićJevtić, 2008) u kojima je ustanovljena značajna netivna povezanost između agresivnog ponašanja i stepena prihvatanja, dok povezanost prosocijalnog ponašanja i stepena prihvatanja nije utvrđena. Analiza uzroka devojčica tom prilikom nije ukazala na povezanost navedenih oblika ponašanja i stepena prihvatanja, dok je analizom uzroka kod dečaka utvrđena značajna povezanost agresivnosti i stepena prihvatanja. 
Proverom poslednje istraživačke hipoteze o stepenu povezanosti indeksa prihvatanja, odbijanja i socijalnog statusa, broja godina provedenih u vrtiću, socijalne kompetentnosti i antisocijalnog ponašanja, ustanovljena je njihova značajnost i na celokupnom uzorku i posebno za dečake, posebno za devojčice. Naime, posmatrajući ustanovljeni odnos sociometrijskog statusa i broja godina u vrtiću na celokupnom uzorku, zapaža se značajna pozitivna povezanost $(\mathrm{r}=0,389 ; \mathrm{p}<.01)$, koja je prisutna i kod odvojenih uzoraka i s obzirom na pol dece. Takođe, ustanovljena je značajna pozitivna povezanost socijalne kompetentnosti sa brojem godina provedenih u ustanovi za celokupni uzorak $(\mathrm{r}=0,190 ; \mathrm{p}<.05)$, ali njena značajnost nije potvrđena na odvojenim uzorcima za dečake i devojčice. Pokazalo se i da antisocijalno ponašanje za sva tri slučaja (ukupan uzorak, dečaci i devojčice) nije značajno povezano sa brojem godina provedenih u vrtiću, ali da postoji značajna negativna povezanost na ukupnom uzorku $(\mathrm{r}=-0,423 ; \mathrm{p}<.01)$, kao i na pojedinačnim uzorcima za dečake i devojčice, između socijalne kompetentnosti i antisocijalnog ponašanja dece.

\section{Zaključna razmatranja}

Sa obzirom na dobijene rezultate, koji ističu pozitivnu vezu između socijalne kompetentnosti predškolaca i prihvatanja od strane druge dece te negatinu vezu između socijalnog razvoja i antisocijalnog ponašanja bez obzira na vreme provedeno u ustanovi, neophodno je naglasiti da teškoće u interakciji sa vršnjacima koje su kod izvesne dece, češće dečaka, vidljive prilikom uključivanja u vršnjačku grupu - ne nestaju same od sebe. One zahtevaju da se odabranim i pažljivo osmišljenim zajedničkim aktivnostima od samog ulaska dece u vaspitnu grupu vežbaju socijalne veštine predškolaca kroz izgrađivanje i ispoljavanje pozitivnih oblika ponašanja uz redukovanje nepoželjnih. Da su takve intervencije i preventivni programi mogući, pokazuju izvesni primeri posebno osmišljenih programa (na primer, hrvatski Integralni metod i prilagođeni američki Paths-Rastem), čije je strategije važno učiniti sastavnim delom savremenih kurikuluma predškolskog vaspitanja i obrazovanja (vidi: Bašić, 2012). U tom smislu, ispitivanje prihvaćenosti u vršnjačkoj grupi, odnosno utvrđivanje sociometrijskog statusa deteta, značajno je primeniti tokom prvih godina boravka u predškolskoj ustanovi uz sistemtsko praćenje napredovanja deteta u socijalnim interakcijama.

Prema strategijama koje u središte predškolskog vaspitanja 
i obrazovanja stavljaju razvoj i jačanje socijalnih (i emocionalnih) kompetencija dece, zadatak vaspitača i drugih zaposlenika u predškolskim ustanovama je da na vreme identifikuju decu koja imaju probleme u ponašanju i koja su neprihvaćena, te da smišljeno modeluju socijalnu klimu grupe inicirajući socijalne igre i aktivnosti koje podstiču grupnu koheziju. Takođe je važno da vaspitači doprinose izgrađivanju pravilnih i pravičnih odnosa među decom i da tome prilagođavaju načine regulisanja discipline i rešavanje konflikata podstičući decu da samostalno deluju. Svakako, decu koja nisu prihvaćena ne treba prepustiti sebi samima, već im treba pomoći, bilo samostalnim akcijama i zalaganjem vaspitača, bilo uključivanjem u interventne programe u saradnji sa roditeljima. Saradnja sa porodicom u cilju razmene informacija o funkcionisanju deteta kod kuće, kao i u vrtiću, gde se ističe uloga pedagoga i ostalih stručnih saradnika koji se bave vaspitno-obrazovnim radom, neophodna je u procesu socijalizacije svakog deteta. Kao posrednici u vaspitno-obrazovnom procesu, oni su u prilici da organizuju razne programe za roditelje u cilju unapređenja roditeljskih kompetencija, odnosono sticanja dodatnih veština i znanja za stimulisanje celovitog razvoja dece. Da bi se pomoglo deci u izgrađivanju i jačanju socijalne kompetentnosti, potrebna je otvorena i jasna komunikacija između roditelja $i$ stručnih saradnika, partnerstvo sa povererenjem i prihvatanjem kako bi roditelji znali da u svakom trenutku mogu zatražiti podršku i pomoć.

Formiranje podsticajnih uslova za izgrađivanje i jačanje socijalne kompetentnosti, te rano identifikovanje dece kojoj je potrebna dodatna podrška za uspostavljanje odnosa sa vršnjacima, temeljni su zadaci svih koji su u kontaktu sa decom predškolskog uzrasta, posebno praktičara različitih profila koji deluju u okviru predškolskih ustanova. 


\section{CORRELATION OF SOCIAL COMPETENCE OF PRESCHOOL CHILDREN WITH ADOPTION IN A GROUP I ANTISOCIAL BEHAVIOR}

\section{SUMMARY}

Abstract: During the first years of a child's life, he/she establishes different socioemotional relationships that shape his/her psycho-social development. In addition to acceptance by members of the family, the socialization of the child specially implies the relationships and acceptance by the peers. Socially competent children use different stimuli from the environment, as well as their personal skills and interests, to participate in the community which they belong to. A child's development and learning are significantly hampered if the incentives for interaction are absent or hindered for quite a long time by inappropriate behaviour of the child and / or the peer rejection. With the intention to act preventively, there has been created a research in five preparatory preschool institutions in Vojvodina. The aim of the research was the correlation between children's social competence $(\mathrm{N}=120)$ and their acceptance among peers, and their tendency to antisocial behaviour. Findings from scaling and sociometry show that preschoolers mutually significantly differ in acceptance, social and anti-social behaviour, where a significant positive correlation has been found between social competence and a number of years spent in the institution, while girls are rated as more competent and more accepted.

There has been observed a significant negative correlation between rejection and social competence in boys, and antisocial behaviour and an estimated competence of children in the pre-school children in total, regardless of their gender. It is found that antisocial behavior is not significantly correlated with the number of years spent in the institution. Creation of stimulating conditions for strengthening the social competence, and early identification of children who need an additional support for establishing and building relationships with peers, are the fundamental tasks of all those who are in contact with preschool children, especially those who work within preschools.

Key words: social competence, acceptance in the peer group, anti-social behaviour, programs for practicing social skills. 


\section{Literatura}

Anning, A., Cullen, J., Fleer, M. (2004). Early Childhood Education: Society and Culture. London: Sage Publications.

Bašić, J. (2012). Socijalno-emocionalno učenje i prevencija rizičnih ponašanja u okruženju predškolskih ustanova, U: Pehlić, I., Vejo, E., i A. Hasanagić (ur.) Suvremeni tokovi u ranom odgoju, (str. 495511), Zenica : Islamski pedagoški fakultet Univerziteta u Zenici.

Glavina, E., Višnjić-Jevtić, A. (2010). Prosocijalno i agresivno ponašanje kao prediktori stupnja prihvaćanja u skupini djece predškolske dobi, Zbornik radova sa skupa Nasilje među djecom i nad djecom, 27.29. studenog 2008.godine, (str. 131-138), Osjek : Filozoski fakultet, Društvo psihologa.

Jurčević-Lozančić, A. (2011). Teorijski pogledi na razvoj socijalne kompetencije predškolskog djeteta, Pedagogijska istraživanja, 8 (2), 271-281.

Katz, L. G., McClellan. D. I. (1999). Poticanje razvoja dječje socijalne kompetencije. Zagreb: Educa.

Klemenović, J. (2014). Perspektiva deteta u jednačini spremnosti za školu, Spremnost za školu u inkluzivnom kontekstu, (str.23-31), Novi Sad: Filozofski fakultet u Novom Sadu.

Marić-Jurišin, S. (2015). Implikacije ekoloških programa na socioemocionalni razvoj dece predškolskog uzrasta iz perspektive održive zajednice - disertacija odbranjena (24.04.2015.) na Filozofskom fakultetu Univerziteta u Novom Sadu

Petrović, J.,Zotović, M.(2007). Prihvaćenostu grupi vršnjaka i emocionalna kompetencija dece preadolescentnog uzrasta, Psihologija, 40 (3), 431-445.

Potkonjak, N. i sar. (2008). Instrumenti za rad školskog pedagoga, Beograd: Pedagoško društvo Srbije. 